Doi: $10.4274 /$ Vhd. 54264

\title{
Hepatit B Virüs Enfeksiyonundan Sonra HBsAg Negatifleșen Olgularda HBV-DNA Düzeylerinin Değerlendirilmesi
}

\author{
The Evaluation of HBV-DNA Levels In Patients who Had Lost Hbsag After Recovery From \\ Hepatitis B Virus Infection
}

\author{
Vicdan KÖKSALDI MOTOR1, Aysel KOCAGÜL ÇELIKBAŞ2, Nurcan BAYKAM2, \\ Sebnem EREN GÖK2, Başak DOKUZOĞUZ2 \\ ${ }^{1}$ Mustafa Kemal Üniversitesi Tıp Fakültesi, Enfeksiyon Hastalıkları ve Klinik Mikrobiyoloji Anabilim Dalı, Hatay, Türkiye \\ 2Numune Eğitim ve Araştırma Hastanesi, Enfeksiyon Hastalıkları ve Klinik Mikrobiyoloji Kliniği, Ankara, Türkiye
}

\begin{abstract}
ÖZET
Amaç: Hepatit B enfeksiyonu geçiren kişilerin kanında HBsAg negatifleşse de hepatit $B$ virüsünü bulaştırma riskinin devam ettiği bildirilmektedir.

Gereç ve Yöntemler: Çalışmamızda; hepatit B enfeksiyonu geçiren ve $\mathrm{HBsAg}$ negatifleşen olgularda, hepatit B virüs DNA'sının polimeraz zincir reaksiyonu yöntemi ile araștıııması amaçlandı. Toplam 57 olgu değerlendirmeye alındı. Akut hepatit B virüs enfeksiyonu geçirip $\mathrm{HBsAg}$ negatifleşen 44 olgunun 19'unda $(\% 43,2)$ hepatit B virüs DNA pozitif saptandı.

Bulgular: Doğal immünitesi olup antiHBs pozitif saptanan 13 olgunun ise 2'sinde $(\% 15,4)$ hepatit B virüs DNA'sı pozitif bulundu. Toplam 21 (\%36,8) olguda enfektivitenin devam ettiği gözlendi. Bu olgularda hepatit $B$ virüs DNA düzeyleri 4,6x102 ile $1 \times 10^{5}$ genom/ $\mathrm{mL}$ arasında saptandı.

Sonuç: Çalışmamızda hepatit B virüs enfeksiyonu geçirip HBsAg negatifleşen olgularda HBV-DNA'nın pozitif olabileceği görülmüştür. Bu nedenle; kan donörü seçiminde antiHBc bakı masının $\mathrm{HBsAg}$ aramaya göre daha güvenilir olduğu, organ transplantasyonu uygulamalarında ise HBV serolojik göstergelerinden herhangi birinin pozitif bulunduğu vericilerde, serum ve dokularda polimeraz zincir reaksiyonu ile hepatit $B$ virüs DNA aranmasının uygun olacağı düşüülmektedir. (Viral Hepatit Dergisi 2012; 18(2): 47-51)
\end{abstract}

Anahtar Kelimeler: Hepatit B, kan vericileri, polimeraz zincir reaksiyonu

\section{ABSTRACT}

Objective: The risk of transmitting hepatitis $B$ virus has been reported to continue in the blood of people with loss of HBsAg after recovery from hepatitis B virus infection. The aim of the present study was to investigate the hepatitis B virus DNA in patients with loss HBsAg after recovery from hepatitis $B$ virus infection by using polymerase chain reaction.

Materials and Methods: Total 57 cases were evaluated. Hepatitis B virus DNA was detected in $19(43.2 \%)$ of 44 patients with loss of HBsAg after acute hepatitis $B$ virus infection, and in $2(15.4 \%)$ of 13 cases who had natural immunity with positive antiHBs.

Results: Infectivity continued in $21(36.8 \%)$ cases. Hepatitis B virus DNA levels were detected between $4.6 \times 10^{2}$ with $1 \times 10^{5}$ genome $/ \mathrm{mL}$ in these serum samples. Conclusion: In our study, hepatitis B virus DNA can positive in patients with loss of $\mathrm{HBsAg}$ after hepatitis B virus infection have been shown. For this reason, antiHBc screening more reliable than HBsAg was thought in the selection of blood donors. It was thought that hepatitis B virus DNA testing with polymerase chain reaction is appropriate in serum and tissues of donors with positive hepatitis $B$ virus serology in the organ transplantation practices. (Viral Hepatitis Journal 2012; 18(2): 47-51)

Key words: Blood donors, hepatitis B, polymerase chain reaction

\section{Giriș}

Hepatit B virüs (HBV) enfeksiyonu tüm dünyada yaygın olup, yaklașık 400 milyon kişinin bu virüs ile enfekte olduğu bildirilmektedir (1). Erişkin akut hepatit B olgularının \%1-5'i kronikleşmekte, kronikleşen olgularda siroz ve hepatosellüler kanser gelişme riski artmaktadır (2).

Kanda HBsAg'nin varlığı HBV enfeksiyonunun en önemli göstergesidir. HBV enfeksiyonu geçiren kişilerde antiHBs'nin oluşması iyileşmeyi ve immüniteyi gösterir. AntiHBs ile birlikte

Yazıșma Adresi/Address for Correspondence: Dr. Vicdan Köksaldı Motor, Mustafa Kemal Üniversitesi Tıp Fakültesi, Enfeksiyon Hastalıkları ve Klinik Mikrobiyoloji Anabilim Dalı, Hatay Tel.: +90 3262291000 E-mail: vicdanmotor@yahoo.com.tr Received/Geliş tarihi: 24.07.2012 Accepted/Kabul tarihi: 27.08 .2012 
saptanan antiHBc lgG pozitifliği doğal immünite olarak tanımlanır. HBV-DNA'nın serumda bulunması ise viral replikasyonun devam ettiğinin bir ifadesidir (3).

Nükleik asit amplifikasyon yöntemlerinden biri olan polimeraz zincir reaksiyonu (PZR) yöntemi ile HBV-DNA'nın saptanması HBsAg pozitifliğine benzer şekilde HBV enfeksiyonunun kanıtı olarak değerlendirilmektedir $(3,4)$.

HBsAg negatif iken transaminaz yüksekliği bulunan donörlerin \% 9'unda HBV-DNA saptanması, serolojik olarak HBV gösterilemeyen fakat HBV-DNA tespit edilen kişilerin serumlarının verildiği deney hayvanlarında HBV enfeksiyonu oluşması; HBsAg yokluğunda da viral replikasyonun devam edebildiğini ve bu kişilerden parenteral yolla HBV bulaşının mümkün olabildiğini göstermektedir (5-7).

$\mathrm{Bu}$ çalışmada, hepatit B enfeksiyonu geçiren ve HBsAg negatifleşen olgularda bulaş intimalini gösteren HBV-DNA varlığının PZR yöntemi ile araştırılması amaçlandı.

\section{Gereç ve Yöntem}

Çalışmamızda; 2000-2004 yılları arasında Ankara Numune Eğitim ve Araştırma Hastanesi 1. Enfeksiyon Hastalıkları ve Klinik Mikrobiyoloji Kliniği'nde akut HBV enfeksiyonu tanısı ile yatırılarak takip edilen ve HBsAg negatifleşen 44 olgu ile polikliniğimize başvuran ve HBV'ye karşı doğal immünite geliştiği tespit edilen 13 olgu çalışma grubunu oluşturdu. Akut HBV enfeksiyonu sonrasında antiHBs oluşumu gözlenen olgular ile HBsAg negatifleşmesine rağmen 3 ay boyunca antiHBs oluşumu gözlenmeyen olgulardan periferik venöz kan örnekleri toplandı. Bu hastalar 6 ay aralarla kontrole çağrıldı. Bu 44 hastanın sadece 14'ü kontrole geldi. Farklı zamanlarda kontrole gelen 14 olgudan ikinci kan örneği alındı. Böylece 44 hastanın 30'undan tek serum, 14'ünden çift serum örneği alınmış oldu. Polikliniğe başvuran ve HBV'ye karşı doğal immün tanısı alan 13 olgudan ise tespit sırasında bir kez periferik venöz kan örnekleri alındı. Sonuçta çalışmaya alınan 57 olgudan toplam 71 serum örneği toplandı.

Olgulara akut hepatit B tanısı serolojik testlerden HBsAg ve/veya antiHBc IgM pozitifliği yanında $A L T, A S T$, direkt ve indirekt bilirubin, GGT, ALP, LDH değerlerinde yükseklik saptanması ile kondu.

Daha önce sarılık geçirme ve aşılanma öyküsü olmayan; HBsAg negatif, antiHBs ve antiHBc IgG pozitif olan, ALT, AST, direkt ve indirekt bilirubin, GGT, ALP, LDH değerleri normal saptanan kişiler ise doğal immün olarak kabul edildi. Hepatit B serolojik göstergeleri ELISA (Abbott ${ }^{\circledR}$ ) yöntemiyle çalışıldı.
Elli yedi olgudan toplanan 71 kan örneğinin serumları ayrılarak çalışma gününe kadar $-20{ }^{\circ} \mathrm{C}$ 'de saklandı. Bu serum örneklerinde Real-time PZR yöntemi ile HBV-DNA düzeyleri belirlendi.

Serumdan HBV-DNA izolasyonu, "High Pure Viral Nucleic Acid" (Roche, Indianapolis, USA) kiti içerisinde bulunan kullanma kitapçı̆̆ındaki yöntem izlenerek yapıldı. Real-time PZR için Roche Light Cycler cihazı "LightCycler-Fast Start DNA Master Hybridization Probes" kullanıldı (Kat. No: 3003248, Roche, Almanya).

Kullanılan primer ve problar ise HBV ayw genomuna spesifik aşağıdaki sekansları içeriyordu:

HBV-305-321 5'-GCCAAAATTCGCAGTCC-3' (forward)

HBV-680-663 5'-AAACTGAGCCAGGAGAAA-3' (reverse)

HBV-PR-1 5'-GGATGTGTCTGCGGCGTTTTATCA-

fluorescein-3'

HBV-PR-2 5'-LC-Red

640-TTCCTCTTCATCCTGCTGCTATGCC-fosfat 3'

Fast Start DNA hibridizasyon kiti kullanılarak toplam $20 \mu \mathrm{l}$ içerisinde amplifikasyon yapıldı.

Reaksiyon basamakları tamamlandıktan sonra floresan işaretli probların ortamda bulunan HBV-DNA'ya bağlanması ile oluşan ışıma standartlarla karşılaştırılarak, serumlarda bulunan HBV-DNA düzeyleri kantitatif olarak hesaplandı. Çalışmada $1 \times 10^{2}$ genom/mL'nin altındaki değerler tespit edilemediği için negatif olarak değerlendirildi.

\section{Bulgular}

Yaş dağııımı 16-69 arasında bulunan 57 olgunun 29'u erkek ve 28 'i kadından oluşuyordu. Olguların tamamında serum örnekleri alındığı sırada ELISA ile antiHBe ve antiHBc IgG pozitif, ALT, AST, GGT, direkt ve indirekt bilirubin düzeyleri normal sınırlarda bulundu.

Akut hepatit B enfeksiyonu geçiren hastaların takibinde ilk üç ay içinde HBsAg'nin negatifleştiği gözlendi. HBsAg negatifleştikten sonra tek serum örneği alınan 30 hastanın 19'unda antiHBs pozitif bulunurken; 11 hastada antiHBs negatif saptandı. Iki kez serum örneği alınan 14 olgunun 11'inde her iki

\begin{tabular}{|lccc|}
\hline \multicolumn{4}{|c|}{ Tablo 1. Olgularda HBV-DNA sonuçları } \\
\hline $\begin{array}{c}\text { HBsAg negatişeşen } \\
\text { hastalar } \mathbf{n}(\%)\end{array}$ & $\begin{array}{c}\text { Doğal immün } \\
\text { olgular } \mathbf{n}(\%)\end{array}$ & $\begin{array}{c}\text { Toplam } \\
\mathbf{n}(\%)\end{array}$ \\
\hline HBV-DNA (+) & $19(43,2)$ & $2(15,4)$ & $21(36,8)$ \\
HBV-DNA (-) & $25(56,8)$ & $11(84,6)$ & $36(63,2)$ \\
Toplam & $44(100)$ & $13(100)$ & $57(100)$ \\
\hline
\end{tabular}

Tablo 2. Serum örneklerinde HBV-DNA sonuçları

\begin{tabular}{lccccc}
\hline & $\begin{array}{c}\text { Tek serum örneği } \\
\text { alınan hastalar } \\
\mathbf{n}(\%)\end{array}$ & $\begin{array}{c}\text { Çift serum örneği alınan hastalar } \\
\text { 1. serum örnekleri } \\
\mathbf{n}(\%)\end{array}$ & $\begin{array}{c}\text { 2. serum örnekleri } \\
\mathbf{n}(\%)\end{array}$ & $\begin{array}{c}\text { Doğal immün } \\
\text { olgular } \\
\mathbf{n}(\%)\end{array}$ & Toplam \\
\hline HBV-DNA (+) & $7(23,3)$ & $10(71,4)$ & $7(50)$ & $2(15,4)$ & $26(36,6)$ \\
HBV-DNA (-) & $23(76,7)$ & $4(28,6)$ & $7(50)$ & $11(84,6)$ & $45(63,4)$ \\
Toplam & $30(100)$ & $14(100)$ & $14(100)$ & $13(100)$ & $71(100)$ \\
\hline
\end{tabular}


serum örneğinde antiHBs pozitif saptandı. Iki olguda ilk serum örneklerinde antiHBs negatif iken ikinci örneklerde pozitifleştiği gözlendi. Bir olgu ise 23 ay süresince takip edilmesine rağmen her iki serum örneğinde de antiHBs oluşumu gözlenmedi. Hepatit B'ye karşı doğal immün olan olguların serumları ile birlikte baktığımızda toplam 71 serum örneğinin 56'sında antiHBs pozitif bulunurken; 15 serum örneğinde antiHBs negatif bulundu.

Akut hepatit B geçiren 44 hastanın 19'unda (\%43,2), HBsAg negatifleştikten sonra değişik zamanlarda alınan serum örneklerinde HBV-DNA pozitif bulundu. Doğal immünitesi olan 13 olgunun ise ikisinde $(\% 15,2)$ HBV-DNA pozitif saptandı. Bu iki kişinin HBV-DNA değerleri $3.2 \times 10^{3}$ genom/mL ve $5.2 \times 10^{2}$ genom/mL olarak belirlendi. Toplam 21 (\% 36.8) olguda enfektivitenin devam ettiği gözlendi (Tablo 1).

Elli yedi olgudan toplanan 71 serum örneğinin 26'sında $(\% 36,6)$ HBV-DNA pozitif olarak bulundu. Bu örneklerde HBVDNA düzeyleri 4,6×102 ile $1 \times 10^{5}$ genom $/ \mathrm{mL}$ arasında saptandı. Hastalardan biri akut enfeksiyonu geçirdikten sonra uzun süre kontrole gelmeyip taburuculuğundan 58 ay sonra polikliniğimize başvurdu. Bu olguda antiHBs pozitif olmasına rağmen serum HBV-DNA düzeyi $1 \times 10^{5}$ genom/mL olarak tespit edildi. Olgulardan toplanan 71 serum örneğinde HBV-DNA sonuçları Tablo 2' de gösterilmiştir.

Iki serum örneği bulunan 14 hastanın HBV-DNA sonuçları değerlendirildiğinde; iki olguda her iki serum örneğinde de HBVDNA negatif bulundu. Beş olguda ilk serum örneğinde 102-103 genom/mL düzeyinde pozitif bulunan HBV-DNA düzeyleri azalarak ikinci serum örneklerinde tespit edilemez düzeye indi. HBV-DNA düzeyleri 103-104 genom/mL saptanan beş olgunun ikinci serum örneklerinde de HBV-DNA pozitif bulundu. Ilk serum örneklerinde HBV-DNA tespit edilemeyen iki olgunun 24. ve 15. aylarda alınan ikinci serum örneklerinde HBV-DNA, $10^{3}$ genom/mL düzeyinde bulundu (Tablo 3).

\begin{tabular}{|lcccc|}
\hline \multicolumn{5}{c}{ Tablo 3. Çift serum örneği alınan 14 hastanın HBV-DNA düzeyleri } \\
\hline $\begin{array}{c}\text { Zaman } \\
\text { (ay) }\end{array}$ & $\begin{array}{c}\text { HBV-DNA } \\
\text { (genom/mL) }\end{array}$ & $\begin{array}{c}\text { Zaman } \\
\text { (ay) }\end{array}$ & $\begin{array}{c}\text { HBV-DNA } \\
\text { (genom/mL) }\end{array}$ \\
\hline 1 & 4 & $(-)$ & 11 & $(-)$ \\
2 & 7 & $(-)$ & 13 & $(-)$ \\
3 & 3 & $1,2 \times 10^{3}$ & 14 & $(-)$ \\
4 & 16 & $2,5 \times 10^{3}$ & 24 & $(-)$ \\
5 & 3 & $2,7 \times 10^{3}$ & 14 & $(-)$ \\
6 & 8 & $4,6 \times 10^{2}$ & 26 & $(-)$ \\
7 & 10 & $6,1 \times 10^{2}$ & 23 & $(-)$ \\
8 & 19 & $1,1 \times 10^{4}$ & 26 & $2 \times 10^{4}$ \\
9 & 13 & $1,4 \times 10^{3}$ & 20 & $2 \times 10^{3}$ \\
10 & 12 & $3 \times 10^{3}$ & 21 & $8,8 \times 10^{3}$ \\
11 & 15 & $6,7 \times 10^{3}$ & 34 & $8,4 \times 10^{3}$ \\
12 & 3 & $7,5 \times 10^{3}$ & 10 & $9,6 \times 10^{3}$ \\
13 & 13 & $(-)$ & 24 & $1,3 \times 10^{3}$ \\
14 & 5 & $(-)$ & 15 & $2 \times 10^{3}$ \\
\hline
\end{tabular}

\section{Tartışma}

Akut HBV enfeksiyonu sonrasında HBsAg'nin kaybolup antiHBs'nin oluşması ve karaciğer fonksiyonlarının normale dönmesi; enfeksiyonun iyileştiğinin ve bağışıklık geliştiğinin kanıtı olarak kabul edilir. Fakat virüsün yapısı ve yerleşimi nedeniyle akut HBV enfeksiyonundan klinik, biyokimyasal ve serolojik iyileşme olsa bile viral DNA'nın tamamı yok edilemeyebilir (8-10). Yapılan çalışmalar geçmişte HBV enfeksiyonu geçiren, HBsAg kaybolan ve HBV'na karşı antikor taşıyan olguların yaklaşık \%30'unda vireminin sürdüğünü göstermektedir. Literatürde antiHBs oluşumundan uzun süre sonra bile karaciğer ve serumda HBV-DNA varlığının gösterildiği olgular bulunmaktadır (8,10-13).

Akut hepatit B seyrinde viremi süresinin araştırıldığı bir çalışmada akut HBV enfeksiyonu tanısı ile izlenen 11 hastanın 10'unda 6-19. aylarda HBV-DNA'nın pozitif olduğu saptanmış, sadece bir hastada 14. ayda HBV-DNA'nın negatif olduğu bildirilmiştir (10). Bizim çalışmamızda da 44 hastanın 19'unda 358. aylarda HBV-DNA pozitif olarak bulunmuştur.

Akut HBV enfeksiyonu sonrası HBsAg'i kaybolup antiHBs gelişen dört hastanın uzun süre takip edildiği bir çalışmada olgulardan birinde klinik, biyokimyasal ve serolojik iyileşmeden 70 ay sonra bile serum ve periferal kan mononükleer hücrelerinde HBV-DNA'nın varlığı gösterilmiştir (8). Çalışmamızda akut enfeksiyon tablosunu geçirip 58 ay sonra kontrole gelen ve antiHBs pozitif saptanan bir olguda HBV-DNA düzeyi $1 \times 10^{5}$ genom/mL olarak bulunmuştur. Bu olgu HBV-DNA tespit edilen hastalar arasında, kontrol süresi en uzun ve en fazla viral yüke sahip olan olgu olarak belirlenmiştir.

Rehermann ve ark. 23 yıl önce HBsAg negatifleştiği bilinen bir olguda PZR ile HBV-DNA'yı pozitif bulduklarını bildirmişlerdir (11). HBV enfeksiyonunu ne zaman geçirdiği belli olmayıp, doğal immünite tanısı ile çalışmamıza dahil ettiğimiz 13 kişinin ikisinde hala HBV-DNA'nın pozitif bulunması da virüsün uzun süre serumda varlığını sürdürebileceği görüşünü desteklemektedir.

Bir çalışmada HBsAg negatif, antiHBc pozitif bulunan 63 olgunun 20'sinde Cobas Amplicor PZR ile serumda HBV-DNA (1000 genom/mL altında) pozitif saptanmıştır (12). Bizim çalışmamızda da HBsAg'i kaybolan ve antiHBc pozitif olan 57 olgunun 21'inde Real-time PZR ile HBV-DNA 460-100000 genom/mL arasında pozitif saptanarak benzer sonuçlara ulaşılmıştır.

Zhang ve ark. kronik karaciğer tanısı olan 410 olguda yaptıkları bir çalışmada; olguların tamamında serumda, 188 olgunun ise karaciğerinde PZR ile HBV-DNA araştırmışlar, HBsAg negatif, antiHBs pozitif 84 hastanın \%30'unda serumda; 37 hastanın ise \%32'sinde karaciğerde HBV-DNA'nın pozitif olduğunu bildirmişlerdir (13).

Bildirilen sonuçlar organ transplantasyonlarında HBV'nin alıcıya geçerek enfeksiyon oluşturabilmesi yönünden önemli gözükmektedir. Bazı çalışmalar HBsAg negatif, antiHBc pozitif donörlerden naiv alıcılara yapılan transplantasyonlardan sonra alıcılarda HBV enfeksiyonunun geliştiğini bildirmektedir $(14,15)$. Organ transplant alıcı ve donörlerinin incelendiği sistematik bir 
analizde; HBsAg negatif, antiHBc pozitif donörlerden HBV naiv proflaksi almamış alıcılara yapılan karaciğer nakillerinin \%58'inde yeni HBV enfeksiyonu geliştiği bildirilmiştir. Proflaksi alanlarda bu oran düşse de (\%11) alıcılara HBV geçişi engellenememiştir (16). Benzer bir çalışmada HBsAg negatif, antiHBc pozitif organ donörlerinin alıcıları izlenmiş, 36 karaciğer alıcısının 8'inde HBV enfeksiyonu geliştiği bildirilmiştir (17).

Bazı çalışmalarda da HBV enfeksiyonu geçirip tamamen iyileşmiş alıcılarda kemik iliği transplantasyonu sonrası immünosupresif tedavi veya malinitelerde kemoterapi altında HBV'nin reaktive olabildiği, antiHBs'nin kaybolup HBsAg'nin yeniden oluştuğu belirtilmektedir (18-20).

Transfüzyon sonrası HBV enfeksiyon riski Amerika ve Almanya gibi HBV açısından düşük endemisiteli bölgelerde $1 / 100000$ 'den daha az olarak bildirilmektedir (24). Yüksek endemik bölgelerde bu oranın daha yüksek olacağı kesindir. Örneğin Gana'da kan vericilerinin yaklaşık \%15'inin kronik HBV taşıyıcısı olduğu gösterilmiştir (25). Türkiye ise orta endemisite bölgeleri arasında yer almaktadır (2). Bin dokuz yüz yetmiş yılından bu yana uygulanan tüm kan donörlerinde HBsAg taraması kan transfüzyonu ile geçen HBV enfeksiyonu riskini belirgin olarak azaltmıştır (21). Buna rağmen $\mathrm{HBsAg}$ ve antiHBs negatif, antiHBc pozitif donörlerin kanının verilmesi ile alıcıda transfüzyon sonrası HBV enfeksiyonu gelişebildiği gösterilmiştir $(22,23)$. Çeşitli araştırmalarda kan donörlerinde HBsAg taramasının transfüzyon sonrası HBV enfeksiyon riskini önlemede yetersiz kaldığı, antiHBc taramasının gerekli olduğu sonucuna varılmıştır $(11,26,27)$. Türkiye'den Bal ve ark.'nın kan donörlerinde yaptıları çalışmada, izole antiHBc pozitif donörlerde HBV-DNA pozitifliği tüm HBsAg negatif donörlerin \% 0,011 gibi az bir kısmında tespit edilmiştir. Bu çalışmada, HBV geçişinin bu yolla düşük olmasına rağmen yine de akılda tutulması gerektiği vurgulanmıştır (28). Özkan ve ark. ise HBsAg ve antiHBs yerine antiHBc bakılarak, antiHBc pozitif kişilerde HBsAg ve antiHBs bakılmasının maliyeti \%11,78 azalttığını göstermişlerdir (29).

Weber, HBV-DNA düzeyi ile hastalığın aktivitesi ve enfektivitesi arasında ilişki olduğunu bildirmektedir. Buna göre; çok yüksek viremide (HBV-DNA düzeyi 109-1011 genom/mL) kan yoluyla, cinsel yolla ve aile içi bulaş olduğu; yüksek viremi durumunda (HBV-DNA düzeyi 105-106 genom/mL) kan yoluyla bulaş olduğu ancak cinsel yol ve aile içi bulaşın şüpheli olduğu ifade edilmektedir. Düşük viremi $\left(10^{3}-10^{5}\right.$ genom $\left./ \mathrm{mL}\right)$ ve çok düşük viremide (10-103 genom $/ \mathrm{mL}$ ) ise cinsel yol ve aile içi bulaşın olmadığı ancak kan yoluyla bulaşma olduğu belirtilmektedir (30). Bu sonuca göre bizim çalışmamızda HBVDNA pozitif tespit edilen tüm olgular kan veya organ vericisi olduklarında HBV bulaştırma riskine sahiptirler.

HBV-DNA düzeylerinin zaman içinde dalgalanmalar gösterdiği bildirilmektedir. Tetkik yöntemleri hala standardize edilmediği için HBV-DNA testlerinin prognoz tayininde tek belirleyici olarak kullanılması önerilmemektedir (3,31). Bizim çalışmamızda da farklı zamanlarda alınan çift serum örneğindeki HBV-DNA düzeylerine bakılan 14 olgunun ikisinde HBV-DNA düzeyi ölçülemez halde iken ikinci serum örneklerinde belirgin bir artış olduğu saptanmıştır.
Çalışmamızda HBV enfeksiyonu geçirip HBsAg negatifleşen olgularda HBV-DNA'nın pozitif olabileceği görülmüştür. Bu nedenle; kan donörü seçiminde antiHBc bakılmasının HBsAg aramaya göre daha önemli bir gösterge olduğu, organ transplantasyonu uygulamalarında ise HBV serolojik göstergelerinden herhangi birinin pozitif bulunduğu vericilerde, serum ve dokularda PZR ile HBV-DNA aranmasının uygun olacağı düşünülmektedir.

\section{Kaynaklar}

1. Liu CJ, Chen PJ, Chen DS, Kao JH. Hepatitis B virus reactivation in patients receiving cancer chemotherapy: natural history, pathogenesis, and management. Hepatol Int. 2011; DOI 10.1007/s12072-011-9279-6.

2. Kantarçeken B. Kronik Hepatit B doğal seyir. In: Viral Hepatit 2009. Tabak F, Balık I (eds). Viral Hepatitle Savaşım Derneği, 2009; 3-22.

3. Koziel MJ, Thio CL. Hepatitis B virus and Hepatitis Delta virus. In: Principles and Practice of Infectious Diseases. Mandell GL, Bennett JE, Dolin R (eds). Philadelphia, Churchill Livingstone, 2010; 2059-2086.

4. Özacar T. Hepatit B Virusu, Hepatit Virusları. In: Infeksiyon Hastalıkları ve Mikrobiyolojisi. Topçu AW, Söyletir G, Doğanay M (eds). Nobel Tıp Kitapevleri, 2008; 1882-1904.

5. Hoofnagle JH, Seefe LB, Bales ZB, Zimmerman HJ. Type B hepatitis after transfusion with blood containing antibody to hepatitis B core antigen. N Engl J Med. 1978; 298: 1379-83.

6. Thiers $V$, Nakajima E, Kremsdorf D, Mack D, Schellekens $H$, Driss $F$, et al. Transmission of hepatitis B from hepatitis-Bseronegative subjects. Lancet. 1988; 2: 1273-6.

7. Lai ME, Farci P, Figus A, Balestrieri A, Arnone M, Vyas GN. Hepatitis $B$ DNA in the serum of Sardinian blood donors negative for the hepatitis B surface antigen. Blood. 1989; 73: 17-19.

8. Michalac TI, Pasquınelli C, Guilhot S, Chisari FV. Hepatitis B virus persistence after recovery from acute viral hepatitis. J Clin Invest. 1994; 93: 230-9.

9. Hennig H, Puchta I, Luhm J, Schlenke P, Goerg S, Kirchner H. Frequency and load of hepatitis B virus DNA in first-time blood donors with antibodies to hepatitis B core antigen. Blood. 2002; 100: 2637-41.

10. Yotsuyanagi H, Yasuda K, lino S, Moriya K, Shintani Y, Fujie H, et al. Persistent viramia after recovery from self-limited acute hepatitis B. Hepatology. 1998; 27: 1377-82.

11. Rehermann B, Ferrari $C$, Pasquinelli $C$, Chisari FV. The hepatitis $B$ virus persists for decades after patients recovery from acute viral hepatitis despite active maintenance of a cytotoxic Tlymphocyte response. Nat Med. 1996; 2: 1104-8.

12. Noborg U, Gusdal A, Horal P, Lindh M. Levels of viraemia in subjects with serological markers of past or chronic hepatitis B virus infection. Scand J Infect Dis. 2000; 32: 249-52.

13. Zhang YY, Hansson BG, Kuo LS, Widell A, Nordenfelt E. Hepatitis $B$ virus DNA in serum and liver is commonly found in Chinese patients with chronic liver disease despite the presence of antibodies to HBsAg. Hepatology. 1993; 17: 538-44.

14. Kim HY, Choi JY, Park CH, Song MJ, Jang JW, Chang UI, et al. Adult Living Donor Liver Transplantation Using Hepatitis B Core Antibody-Positive Grafts in Korea, a Hepatitis B-endemic Region. Gut Liver. 2011; 5: 363-6.

15. Cholongitas E, Papatheodoridis GV, Burroughs AK. Liver grafts from anti-hepatitis $B$ core positive donors: a systematic review. J Hepatol. 2010; 52: 272-9.

16. Skagen $C L$, Jou JH, Said A. Risk of de novo hepatitis in liver recipients from hepatitis-B core antibody-positive grafts - a systematic analysis. Clin Transplant. 2011; 25: E243-9.

17. Su WJ, Ho MC, Ni YH, Chen HL, Hu RH, Wu Y, et al. High-titer antibody to hepatitis $B$ surface antigen before liver transplantation can prevent de novo hepatitis B infection. J Pediatr Gastroenterol Nutr. 2009; 48: 203-8. 
18. Sugauchi F, Tanaka $Y$, Kusumoto $S$, Matsuura $K$, Sugiyama $M$, Kurbanov $F_{\text {, et }}$ al. Virological and clinical characteristics on reactivation of occult hepatitis $B$ in patients with hematological malignancy. J Med Virol. 2011; 83: 412-8.

19. Sato K. Immunosuppressive therapy or chemotherapy-induced reactivation of hepatitis B virus infection. Gan To Kagaku Ryoho. 2011: 38: 161-8.

20. Borentain P, Colson P, Coso D, Bories E, Charbonnier A, Stoppa $A M$, et al. Clinical and virological factors associated with hepatitis $\mathrm{B}$ virus reactivation in $\mathrm{HBsAg}$-negative and anti-HBc antibodies-positive patients undergoing chemotherapy and/or autologous stem cell transplantation for cancer. J Viral Hepat. 2010; 17: 807-15

21. Said ZN. An overview of occult hepatitis B virus infection. World J Gastroenterol. 2011; 17: 1927-38.

22. Larsen J, Hetland G, Skaug K. Posttransfusion hepatitis B transmitted by blood from a hepatitis B surface antigennegative hepatitis B virus carrier. Transfusion. 1990; 30: 431-2.

23. Norder H, Hammas B, Larsen J, Skaug K, Magnius LO. Detection of HBV-DNA by PCR in serum from an HBsAg negative blood donor implicated in cases of post-transfusion hepatitis B. Arch Virol Suppl. 1992; 4: 116-8.

24. Schreiber GB, Busch MP, Kleinman SH, Korelitz JJ. The risk of transfusion-transmitted viral infections. The Retrovirus Epidemilogy Donor Study. N Engl J Med. 1996; 334: 1685-90.
25. Allain JP, Candotti D, Soldan K, Sarkodie F, Phelps B, Giachetti C, et al. The risk of hepatitis $B$ virus infection by transfusion in Kumasi, Ghana. Blood 2003; 101: 2419-25.

26. Panigrahi $R$, Biswas A, Datta $S$, Banerjee A, Chandra PK, Mahapatra PK, et al. Anti-hepatitis B core antigen testing with detection and characterization of occult hepatitis $B$ virus by an in-house nucleic acid testing among blood donors in Behrampur, Ganjam, Orissa in southeastern India: implications for transfusion. Virol J. 2010; 7: 204

27. Antar W, El-Shokry MH, Abd El Hamid WA, Helmy MF. Significance of detecting anti-HBc among Egyptian male blood donors negative for HBsAg. Transfus Med. 2010; 20: 409-13.

28. Bal SH, Heper Y, Kumaş LT, Mistik R, Töre O. Investigation of the presence of HBV-DNA in isolated anti-HBc positive cases and their importance in blood banking. Mikrobiyol Bul 2009; 43: 243-50.

29. Ozkan S, Atak A, Bozdayi G, Turkcuoglu S, Maral I. Communitybased research: cost of the tests used for anti-HBc total seropositivity only and hepatitis B screening. Trans R Soc Trop Med Hyg 2010; 104: 782-6.

30. Weber B. Recent developments in the diagnosis and monitoring of HBV infection and role of the genetic variability of the S gene. Expert Rev Mol Diagn 2005; 5: 1-17.

31. Lok AS, Heathcote EJ, Hoofnagle JH. Management of hepatitis B: 2000- Summary of a workshop. Gastroenterology 2001; 120: 1828-53. 